\title{
A CASE REPORT OF IMAGING DIAGNOSTICS OF CALF MUSCLES HERNIA
}

\author{
Goher Abdelalim1, Milyushina Ya.A.2
}

$\mathrm{P}$

urpose. To present clinical observation of a patient with muscle hernias and compare the possibilities of ultrasound and MRI methods for their diagnostics.

Materials and methods. The clinical observation of a 42-year-old male patient with history of insignificant pain in anterolateral aspect of distal third of the right leg in running was de-scribed in the article. A clinical and radiological examination including ultrasound and MRI was provided.

Results. In clinical examination a non-tender soft tissue mass, measuring $1.5 \mathrm{~cm}$, more obvious in muscle contraction was revealed. Ultrasonogram examination showed small focal bulging mass, isoechoic to the rest of the muscle. MRI demonstrated focal bulging mass originating from peroneus longus muscle. Another small muscle hernia at the medial aspect of middle third of the right leg was also detected on MRI.

Conclusion. Muscle hernias of the lower leg are not so rare, especially in active young men. Clinicians should include muscle hernias in the list of differential diagnoses of chronic leg pain and neuropathy. Ultrasound is the preferred diagnostic method because it can be easily used for dynamic examination of a hernia, and define the nature of the mass. MRI can confirm the presence of muscle hernia and determine the hernial muscle and its size, exclude other causes of the mass and illustrate any fascial defects.

Keywords: muscle hernia, myocele, imaging, MRI, ultrasound.

Corresponding author: Goher A., e-mail: alimgoher@gmail.com

For citation: Goher Abdelalim, Milyushina Ya.A. A case report of imaging diagnostics of calf muscles hernia. REJR 2020; 10(2):295-299. DOI:10.21569/2222-7415-2020-10-2-295298.

Received: $\quad 20.04 .20 \quad$ Accepted: $\quad 19.06 .20$

\section{ВИЗУААЬНАЯ АИАГНОСТИКА МЫШЕЧНЫХ ГРЫЖ ГОАЕНИ}

\author{
Гохер Аблелалим', Милюшина Я.А.2
}

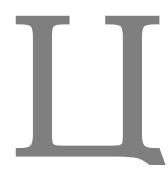

ель исследования. Представить клиническое наблюдение пациента с мышечными грыжами голени и сравнить возможности для их диагностики таких методов, как УЗИ и МРТ.

Материалы и методы. В статье описано клиническое наблюдение 42-летнего пациен-та, жалующегося на незначительную боль в нижней трети правой голени с передне-латеральной стороны, возникающую при беге. Проведено клиническое и мучевое об-следование, включающее ультразвуковое исследование и МРТ.

Результаты. При клиническом обследовании было выявлено безболезненное образо-вание из мягких тканей размером 1,5 см, более выраженное при сокращении мышц. УАьтразвуковое исследование показало небольшое очаговое выпячивание, изоэхоген-ное к остальным мышцам. При МРТ также обнаружено очаговое выпячивающее обра-зование, происходящее из длинной малоберцовой мышцы, а также была выявлена еще одна небольшая мышечная грыжа с медиальной стороны средней трети правой гомени.

Заключение. Мышечные грыжи голени встречаются не так уж редко, особенно у ак-тивных молодых мужчин. КАиницисты должны вкАючить мышечные грыжи в спи-

1 - Radiology department of diagnostic imaging of Dubai Hospital.

Dubai, UAE.

2 - Semey Medical University.

Semey, Republic of Kazakhstan.
1 - Отдемение мучевой диагностики и цифровой рентгенографии госпиталя Дубай.

Дубай, ОАЭ.

2 - Медицинский университет Семей. Семей, Республика Казахстан. 
сок дифференциальных диагнозов хронической боли в ногах и невропатии. УАьтразвуковая диагностика является предпочтительным методом, потому что его можно мегко использовать для исследования грыжи в динамике и определения характера грыжевой массы. МРТ может подтвердить наличие мышечной грыжи, ее размер, определить

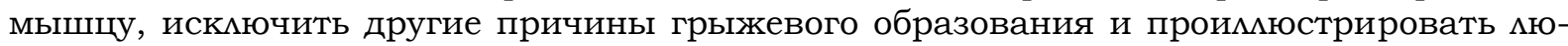
бые фасциальные дефекты.

К^ючевые слова: мышечная грыжа, миоцеле, визуальная диагностика, МРТ, умьтразвуковая диагностика.

Контактный автор: Гохер Абдемалим, e-mail: alimgoher@gmail.com

Для иитирования: Гохер Абделалим, Милюшина Я.А. Визуальная диагностика мышечных грыж голени. REJR 2020; 10(2):295-299. DOI:10.21569/2222-7415-2020-10-2295-298.

\section{Статья получена: $\quad 29.01 .20 \quad$ Статья принята: $\quad$ 03.03.20}

\section{I}

\section{ntroduction.}

Muscle hernia or protrusion of muscle tissue through a defect in the fascia which confines it, has received relatively scant consideration in the literature. The condition, however, is not rare, and a more careful consideration of the subject is warranted, particularly in view of its frequent recognition in military personnel [1]. Original reference to this lesion as a distinct entity was made in 1839 by the eminent French surgeon, Dupuytren, who recorded a muscular hernia, which had been mistaken for a varicose vein [2]. Later, in 1929, Hugo Ihde reported a series of 12 patients with hernias of the leg and provided an excellent comprehensive description and critique of the history of muscle hernias [1].

\section{Case History.}

A 42-year-old Arabic male leading active life style, with old sportive injury of the right leg, presented with history of insignificant pain in anterolateral aspect of distal third of the right leg during running. In examination of above described area a physician revealed a non-tender soft tissue mass, measuring $1.5 \mathrm{~cm}$, more obvious in muscle contraction (Fig. 1).

Ultrasonogram examination showed small focal bulging mass isoechoic to the rest of the muscle. No abnormal vascularity was seen (Fig. 2).

The ultrasonographic findings were confirmed by MRI. MRI demonstrated focal bulging mass originating from peroneus longus muscle, which matches MRI signal similar to all muscle and focal defect of the deep fascia. The MRI also detected another small muscle hernia at the medial aspect of middle third of the right leg (Fig. 3).

We considered the results of patient examination were obvious, so no surgical and histopathological confirmation was provided.

\section{Discussion.}

Published descriptions of muscle herniation in the extremities are sparse. The true incidence of muscle hernias is not known. Some authors believe that the condition is rare, whereas others have described it as common [3]. Verbov J. (1976) considers that asymptomatic small muscle herniae of the lower legs arc said to be not uncommon in those whose legs are exposed to severe chronic strain, such as athletes, heavy manual workers, mountain climbers and soldiers. However, for a patient to present at a clinic with the condition is most uncommon [4]. In the leg, the tibialis anterior is the most commonly involved muscle and the most reported in literature $[1,5,6]$. The fascia of tibialis anterior is the most vulnerable to trauma because it is the weakest fascial point in the lower extremity. Herniation of muscle takes place through hiatuses in the deep fascia where it is perforated by the smaller cutaneous vessels or through fascial splits [4,5]. Muscular hernias of peroneus muscles, however, are rare. There are only several cases reported involving the peroneus muscles [5].

The etiology of muscle hernias includes congenital fascial defects, direct fascial trauma, indirect fascial trauma due to acute muscle action, and multifactorial causes [2]. On clinical examination, muscle hernia may present as a palpable bulge, soft tissue mass, or subcutaneous nodule. It may be solitary, multiple, or bilateral. It is usually reducible on lying down. The patient may complain of pain, discomfort, weakness, cramping, or neuropathy. It worsens with standing and physical activity. On examination, local tenderness and decreased sensation may occur if there is associated nerve involvement [7].

The diagnosis of muscle herniation can be suspected clinically but radiological evaluation is useful for definitive diagnosis to exclude cyst, lipoma or vascular anomaly, as well as other be 

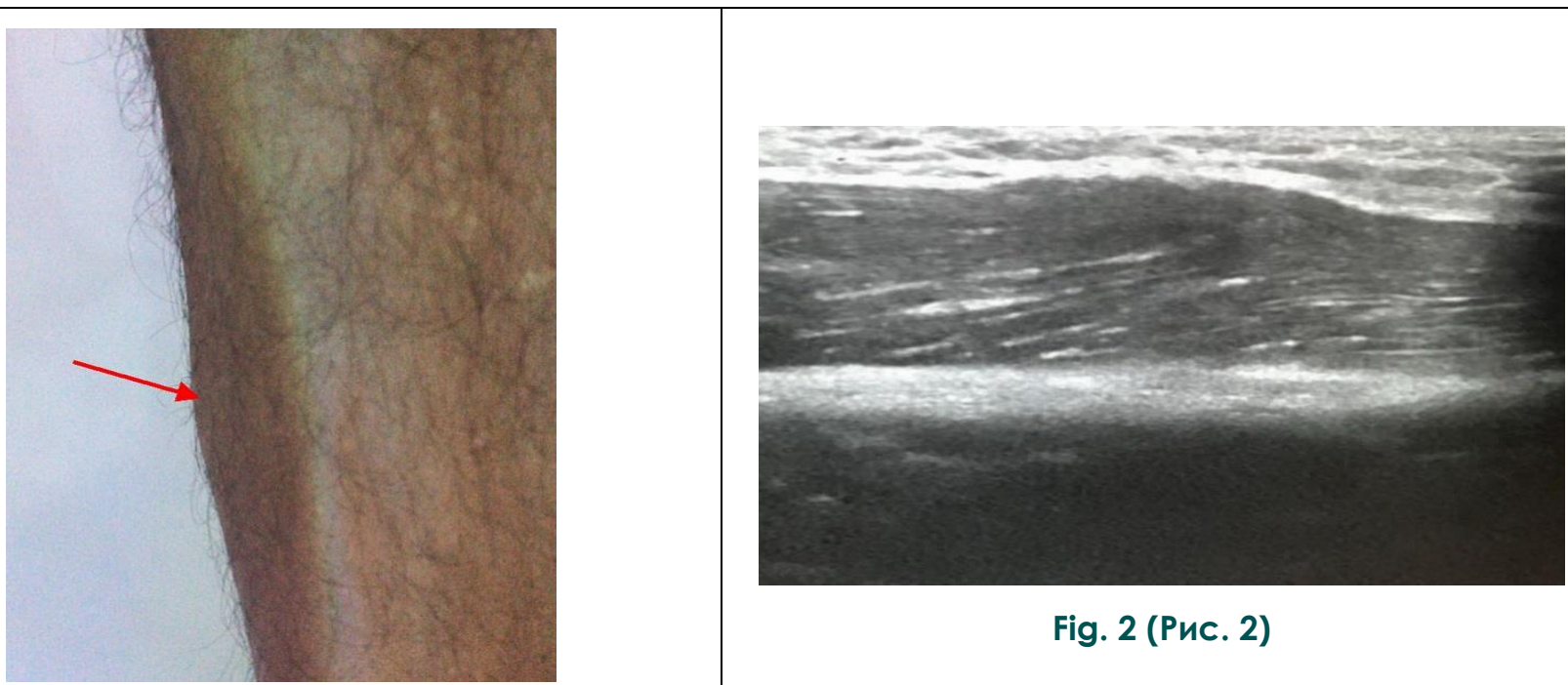

Fig. 2 (Рис. 2)

Fig. 1 (Рис. 1)

\section{Fig. 1. Photo.}

Bulging soft tissue mass, measuring $1.5 \mathrm{~cm}$ in anterolateral aspect of distal third of the right leg.

\section{Рис. 1. Фотографрия.}

Выпячивание мягких тканей дистальной трети правой голени размером 1.5 см в переднебоковом аспекте.

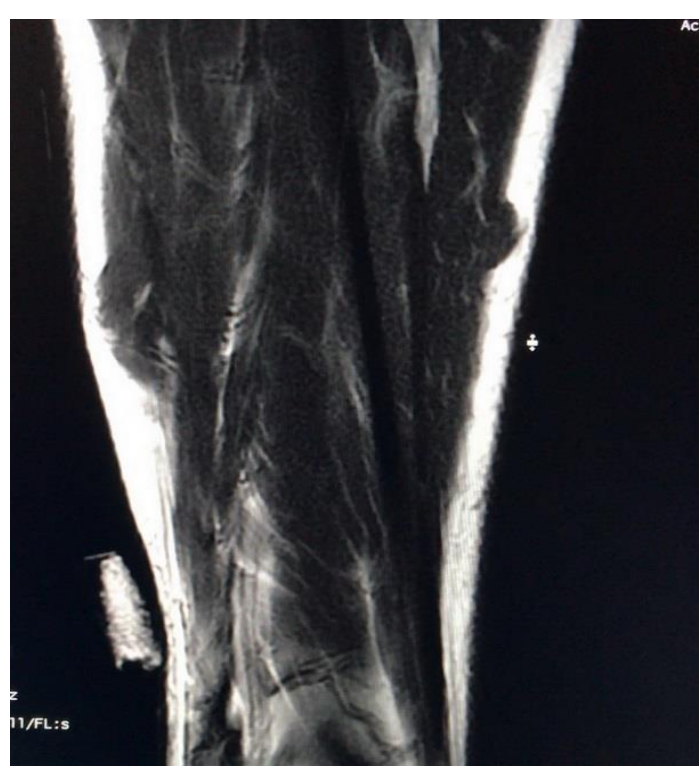

Fig. 3 (Рис. 3)

\section{Puc. 3. MRI, T2-WI, coronal view.}

Two small muscle hernia through a small defect of the deep fascia. MRI signal inten-sity of the herniated muscle is equal to the rest of the muscles.

\section{Fig. 3. МРТ, Т2-ВИ, корональная плоскость.}

Две небольшие мышечные грыжи через дефекты глубокой фасции. МР-сигнал мышечной грыжи идентичен остальной части мышц.

\section{Fig. 2. Ultrasound.}

Focal herniation of the muscle along the deep fascia covering it. Herniation has isoechoic echotexture relative to the muscle.

\section{Рис. 2. УзИ.}

Очаговая мышечная грыжа через покрывающую её глубокую фасцию. По отношению к мышце грыжа изоэхогенна.

nign and malignant neoplasms, especially in the cases with associated soft tissue edema and/or hypertrophy of subcutaneous fat. The presence of a mass may result in imaging. The modes of diagnosis of muscular hernias have been discussed in the literature. Two modalities, ultrasonography and MRI, have been used. Ultrasonography with dynamic imaging and provocative maneuvers is key to diagnosis. US confirmation of a muscle hernia provides a reassuring diagnosis and helps exclude the presence of an aggressive lesion [8]. Dynamic sonography after exercise must be the first imaging examination due to its low cost and ready availability. Small muscle hernias can be missed if excessive transducer pressure is applied; the hernia can be reduced temporarily and thus rendered invisible on sonographic examination. Familiarity with this condition is necessary to avoid misdiagnosis and subsequent delay of treatment. Normal muscle is covered by thin echogenic fascia, and the margins of a defect are usually well defined. The hernia protrudes through a defect in the fascia, which is perpendicular to the direction of sound. This protrusion acquires a mushroom like shape. The muscle fibers in the herniated portion are either parallel or tangential to the sound beam and do not reflect as well (anisotropy effect); therefore, a small hernia becomes imperceptible within the surrounding fat [6]. MRI, although more expensive, is useful for 


\section{RUSSIAN ELECTRONIC JOURNAL OF RADIOLOGY}

confirmation or equivocal ultrasonography results. In actuality, MRI better visualizes musculofascial demarcation, allowing quantification of fascial splitting and muscle herniation. MRI is superior to computed tomography because muscle and fascia have similar attenuation, which is not as easily differentiable on computed tomography [5].

\section{Conclusion.}

Peroneus longus muscle herniation is a rare entity. However, muscle hernias of the leg are not of infrequent occurrence, particularly in active young males. That's why clinicians should include

\section{References:}

1. Simon H.E., Sacchet H.A. Muscle hernias of the leg: review of the literature and report of twelve cases. Am J Surg. 1945; 67: 87-89.

2. Schechter D.C., Palmieri A.J., Vaden O.L. Myocele of the lower limb. Arch Surg. 1961; 83: 825-34.

3. Kramer D.E., Pace J.L., Jarrett D.Y., Zurakowski D., Kocher M.S., Micheli L.J. Diagnosis and management of symptomatic muscle herniation of the extremities: a retrospective review. Am $J$ Sports Med. 2013; 41 (9): 2174-80.

4. Verbov J. Muscle herniation of the lower legs.Br J Dermatol. 1976; 95 (3): 329-30.

5. Nguyen JT, Nguyen JL, Wheatley MJ, Nguyen TA. Muscle muscle hernias in the list of differential diagnoses for chronic leg pain and neuropathy. This case highlights the importance of recognition of this pathology. Ultrasound is advantageous method of diagnostics as it can be used easily to examine the hernia dynamically and the visualization of the hernia by the patient would aid in reassuring the patient regarding the nature of the mass. MRI could confirm the presence of the muscle hernia and identify the herniating muscle and its size, exclude other causes of the mass and illustrate any fascial defects. hernias of the leg: A case report and comprehensive review of the literature. Can J Plast Surg. 2013; 21 (4): 243-7.

6. Gokhale S. Three-dimensional sonography of muscle hernias. J Ultrasound Med. 2007; 26 (2): 239-42.

7. Khaladkar S.M., Kondapavuluri S.K., Kamal A., Kalra R., Kamal V. Detection of Myofascial Herniation on Dynamic Sonography and Magnetic Resonance Imaging. Case Rep Radiol. 2016; 4245189.

8. Jarrett DY, Kramer DE, Callahan MJ, Kleinman PK. US diagnosis of pediatric muscle hernias of the lower extremities. Pediatr Radiol. 2013; 43: S2-7. 